\title{
Haemostatic properties of Vernonia amygdalina and Chromolaena odorata leaf extracts using Wistar rat model
}

\author{
Lucy Omokhegbe Matthew* and Evarista Odaburhine Osime**
}

\begin{tabular}{l} 
ABSTRACT \\
\hline BACKGROUND \\
The leaves of African plants are widely employed in Nigeria to control \\
bleeding from wounds. This work is aimed at evaluating the haemostatic \\
effects of Vernonia amygdalina (VA/bitter leaf) and Chromolaena odorata \\
(CO/sunflower) leaves on some haemostatic parameters.
\end{tabular}

\section{METHODS}

A laboratory study of experimental design was conducted involving 35 Wistar rats that were randomized into seven groups. Groups 1 and 2 received leaf extracts of VA at concentrations of 150 and $250 \mathrm{mg} / \mathrm{kg} \mathrm{BW}$, respectively; groups 3 and 4 received leaf extracts of $\mathrm{CO}$ at 150 and $250 \mathrm{mg} / \mathrm{kg} \mathrm{BW}$; groups 5 and 6 received combined leaf extracts of VA and $\mathrm{CO}$ at 150 and $250 \mathrm{mg} / \mathrm{kg} \mathrm{BW}$, respectively, for 30 days. The last group 7 as control group received only water. Parameters investigated were clotting time (CT), fibrinogen concentration, prothrombin time (PT), activated partial thromboplastin time test (APTT), factor VII, protein C and D - dimer.

\section{RESULTS}

There was a significant reduction in CT, fibrinogen concentration and PT in the intervention groups compared to controls $(p<0.01)$. There was no significant difference in APTT, factor VII and protein $\mathrm{C}$ in the intervention groups compared to the controls ( $\mathrm{p}>0.05)$. $\mathrm{D}$-dimer levels were observed to increase significantly in rats treated with $150 \mathrm{mg} / \mathrm{kg} \mathrm{BW}$ of VA and $150 \mathrm{mg} /$ $\mathrm{kgBW}$ of the combined leaf extracts (VA/CO) compared to the controls $(\mathrm{p}<0.05)$.

\section{CONCLUSION}

The VA and CO extracts reduced CT, PT, fibrinogen concentrations and increased D-dimer levels in rats. This study suggests the possible incorporation of the leave extracts of VA and $\mathrm{CO}$ in bleeding diathesis as well as in coagulation studies.

Keywords: Haemostatic parameter, Vernonia amygdalina, Chromolaena odorata, rats
*Edo State School of Health

Technology, Benin City, Nigeria

**Department of Medical Laboratory

Science, School of Basic Medical

Science, College of Medical Sciences,

University of Benin, Nigeria

\section{Correspondence:}

Dr. (Mrs.) E. O. Osime

Department of Medical Laboratory

Science

School of Basic Medical Science

College of Medical Sciences

University of Benin, Nigeria

Email: evarista.osime@uniben.edu

ORCID ID: https://orcid.org/0000-

0003-4972-9735

Date of first submission, November 21, 2018

Date of final revised submission, July 2,

2019

Date of acceptance, July 10, 2019

This open access article is distributed under a Creative Commons AttributionNon Commercial-Share Alike 4.0

International License

Cite this article as: Matthew LO, Osime EO. Haemostatic properties of Vernonia amygdalina and Chromolaena odorata leaf extracts using Wistar rat model. Univ Med 2019;38:131-8. doi: 10.18051/UnivMed.2019.v38.131 138 


\section{INTRODUCTION}

Whenever blood vessels are damaged, there is an immediate physiological response designed to minimize and arrest blood loss. ${ }^{(1)}$ The sum total of this response is encompassed by the term haemostasis and involves the interaction of the vascular system, platelets, plasma proteins, inhibitors and the fibrinolytic system. ${ }^{(2)}$ The functions of these components are divided into primary and secondary haemostatic mechanisms. The primary haemostatic mechanism involves the vascular system and platelets, while the secondary mechanism involves the plasma protein responses of the coagulation process to injury. The combined effects of these mechanisms lead to the formation of a stable fibrin-platelet plug, vessel healing and dissolution of the plug. ${ }^{(3)}$

Vernonia amygdalina (VA) commonly called bitter leaf is a perennial shrub, $2.5 \mathrm{~m}$ in height, that grows throughout tropical Africa. ${ }^{(4)}$ It belongs to the family Asteraceae and has elliptic leaves that are about $6 \mathrm{~mm}$ in length. The leaves are green and have a characteristics odor and bitter taste. ${ }^{(5)}$ The macerated leaves of the plant are consumed as vegetables and condiments and a source of green leafy vegetable for culinary application as well as for topical treatment of wounds. ${ }^{(6)}$ In many parts of Nigeria the plant has been domesticated. (7) Different ethnic groups in Nigeria ascribe various names to this plant such as Ewuro, Etidot, Onugbu, Chusa-dike, "EbeOriwo" and others. ${ }^{(8)}$

Chromolaena odorata $(\mathrm{CO})$ is a tropical species of flowering shrub in the sunflower family Asteraceae. In Western Africa, it prevents regeneration of tree species in areas of shifting cultivation. The extract has been used to stop bleeding and in wound healing in many tropical countries. It also contains a master regulator of genes with defensive anti-inflammatory and detoxifying functions. ${ }^{(9)}$

In many communities, individuals squeeze and paste these leaves regularly on the affected portion of the injured vessels which stops the bleeding in a short time. The nutritional and medicinal benefits of these vegetables assist in combating malnutrition, prevention of many diseases as well as contributing to the food security system in rural areas. ${ }^{(4)}$

Medicinal plants have formed the basis of health care throughout the world since the earliest days of humanity and have remained relevant in both the developing and developed nations for various chemotherapeutic purposes. ${ }^{(10)}$ The use of plant- derived natural compounds as part of herbal preparations form an alternate source of medication. The leaf extract of Vernonia amygdalina has been found to possess ethnomedical and pharmacological properties, such as antidiabetic, antimalarial and antihelminthic effects. ${ }^{(11,12)}$

Previous studies done on this leaf extract investigated the first-line routine investigation in bleeding episodes and the healing process. ${ }^{(12)}$ Our study went further to investigate specific clotting factors and added that increase in D-dimer levels was responsible for the reduction in prothrombin time (PT), stoppage of bleeding which will invariably enhance wound healing. The combination of these two extracts in bringing this about has not been previously investigated.

Against this backdrop, this work was carried out to evaluate the effect of Vernonia amygdalina and Chromolaena odorata leave extracts on some haemostatic parameters using Wistar rats.

\section{METHODS}

\section{Research design}

The extracts of both leaves were analyzed to identify the active ingredients using methods described by Sofowora. ${ }^{(13)}$ Acute toxicity studies using $\mathrm{LD}_{50}$ was carried out before the leaf extracts were administered to the rats. This work was carried out between January and August, 2017 in Benin City, Edo State, Nigeria.

\section{Collection and preparation of plant extract}

Fresh specimens of Vernonia amygdalina and Chromolaena odorata leaves were 
harvested in a farm land in Benin City and identified by a qualified Pharmacist/ Pharmacologist. The extract of the leaves was prepared at the Pharmacognosy Laboratory, Faculty of Pharmacy, University of Benin. The registration numbers of the leaves were UBW/ PCG/1024 and UBW/PCG/1025 for Vernonia amygdalina and Chromolaena odorata respectively.

\section{Acute toxicity testing}

The median lethal dose $\left(\mathrm{LD}_{50}\right)$ is a common test used to evaluate acute toxicity. This was done on twenty (20) rats, using two (2) rats for each concentration by the standard method. Phytochemical screening on both leaves was done by methods described by various researchers. ${ }^{(13,14)}$

\section{Animal treatment}

A total of 35 apparently healthy Wistar rats of both sexes weighing between 140-180 g, obtained from the animal house of the Department of Anatomy, University of Benin, were sorted for the haemostatic evaluation. All experimental animals were fed with standard animal feed and water ad libitum.

\section{Sample size determination}

This was calculated using the Resource Equation

$\mathrm{E}=$ Total number of animals " Total number of groups

Where $E$ is the degree of freedom of analysis of variance (ANOVA). The value of $E$ should lie between 10 and 20. If $E$ is less than 10 then adding more animals will increase the chance of getting more significant results. ${ }^{(15)}$

\section{Experimental animals}

Group 1 received $150 \mathrm{mg} / \mathrm{kg}$ body weight extract of Vernonia amygdalina (VA). Group 2 received $250 \mathrm{mg} / \mathrm{kg}$ body weight VA. Group 3 received $150 \mathrm{mg} / \mathrm{kg}$ body weight extract Chromolaena odorata (CO). Group 4 received
$250 \mathrm{mg} / \mathrm{kg}$ body weight extract Chromolaena odorata (CO). Group 5 received $150 \mathrm{mg} / \mathrm{kg}$ body weight extract combined extract VA/CO. Group 6 received $250 \mathrm{mg} / \mathrm{kg}$ body weight extract combined extract VA/CO leaves. Group 7 served as control group and received water. Leaf extracts were administered once daily via orogastric intubation for 30 days.

\section{Collection of blood samples}

The rats were euthanized under mild concentration of chloroform vapor and sacrificed. Whole blood was collected via cardiac puncture using sterile syringes into EDTA bottles for full blood count and into trisodium citrate bottles for haemostatic factor assay.

\section{Determination of haemostatic parameters Quantitative estimation of protein C}

The enzyme linked immunosorbent assay (ELISA) method was used. The micro ELISA plate was pre-coated with an antibody specific to protein C. Standards and samples were added to the appropriate micro-ELISA plate wells and combined with the specific antibody. A biotinylated detection antibody specific for protein $\mathrm{C}$ and Avidin-Horseradish peroxidase (HRP) conjugate was added to each micro plate successively and the plate incubated. Free components were washed away. The substrate solution was added to each well. The enzyme-substrate reaction was terminated by the addition of a stop solution (sulphuric acid solution) to form a yellow colour. ${ }^{(16)}$

\section{Estimation of factor VII}

One hundred microlitres of standard and sample were added to separate tubes, $100 \mu 1$ of prepared detection reagent $\mathrm{A}$ was added and incubated for $1 \mathrm{hr}$ at $37^{\circ} \mathrm{C}$. They were washed three times using normal saline, $90 \mu$ of substrate solution was added and incubated for 30 minutes at $37^{\circ} \mathrm{C}$. Finally $50 \mu \mathrm{l}$ stop solution was added and the optical density (OD) read spectrophotometrically at $540 \mathrm{~nm} .{ }^{(16)}$ 


\section{Estimation of D-dimers}

Fifty microlitres of standard and sample was measured in separate test tubes. Forty microlitres of biotinylated detection antibody was added immediately and incubated for 45 minutes at $37^{\circ} \mathrm{C}$, then washed three times using normal saline. Ninety microlitres of substrate reagent was added and incubated at $37^{\circ} \mathrm{C}$ for 15 minutes. Fifty microlitres of stop solution was added and the optical density read at $450 \mathrm{~nm}$ immediately. ${ }^{(16)}$

\section{Estimation of plasma fibrinogen concentrate (FC)}

This was done using Ingram's clot weight methods. When calcium chloride is added to citrated plasma, the intrinsic pathway is triggered, resulting in " the formation of a fibrin clot, which can be collected and dried; the weight of fibrinongen obtained is directly proportional to the amount of fibrinogen present. ${ }^{(16)}$

\section{Determination of clotting time (CT)}

The principle of clotting time is based on the time required for a sample of blood to coagulate in vitro under standard conditions. Blood samples collected were immediately placed in test tubes which were already pre-warmed to a temperature of $37^{\circ} \mathrm{C}$ in a water bath, and timing was done immediately with a stop watch. The tubes were swirled gently at 30 second intervals to observe for clot formation. As soon as a clot was observed, the timer was stopped and the time recorded in minutes.

\section{Determination of prothrombin time (PT)}

The Diagen diagnostic reagent was used. The PT test measures the clotting time of plasma in the presence of optimal concentrations of thromboplastin and indicates the overall efficiency of the extrinsic clotting system.

In the presence of calcium ions, tissue thromboplastin initiates the extrinsic coagulation pathway by the direct activation of factor VII to VIIa. This culminates in the conversion of soluble fibrinogen to insoluble fibrin by the direct action of thrombin. A reduction in the concentration of clotting factors of the extrinsic and common pathways will result in the prolongation of the $\mathrm{PT}$, the degree of which is proportional to the level of concentration reduction.

\section{Activated partial thromboplastin time (APTT)}

This was also done using Diagen diagnostic reagent. It is a measure of the combined effect of the clotting factors of the intrinsic and common coagulation pathways. It represents the ultimate refinememt in which platelet activity is standardized by the use of platelet substitutes and contact activation is standardized by preincubation of the plasma with the kaolin platelet substitute mixture for a standard time before recalcification. ${ }^{(16)}$

\section{Statistical analysis}

Result obtained were expressed as mean \pm standard error of mean (SEM). Differences were determined by one-way analysis of variance (ANOVA). Computer software used was Graph pas instat Version 2.05 software/UK. Level of significance was at $\mathrm{p}<0.05$.

\section{Ethical clearance}

All the experiments were performed in accordance with the guidelines for care and use of laboratory animals of the Faculty of Pharamacy, University of Benin. The registration numbers of the leaves wers UBW/PCG/1024 and UBW/ $\mathrm{PCG} / 1025$ for VA and CO respectively.

\section{RESULTS}

There was a significant decrease in PT $(p<0.05), C T$ and $F C(p<0.01)$ in rats treated with $150 \mathrm{mg} / \mathrm{kgBW}$ of the combined extracts when compared to controls (Table 1). D-dimer levels were observed to increase significantly $(p<0.05)$ in rats treated with $150 \mathrm{mg} / \mathrm{kgBW}$ of VA and VA/CO extracts when compared with the controls $(\mathrm{p}<0.05)($ Table 2$)$. 

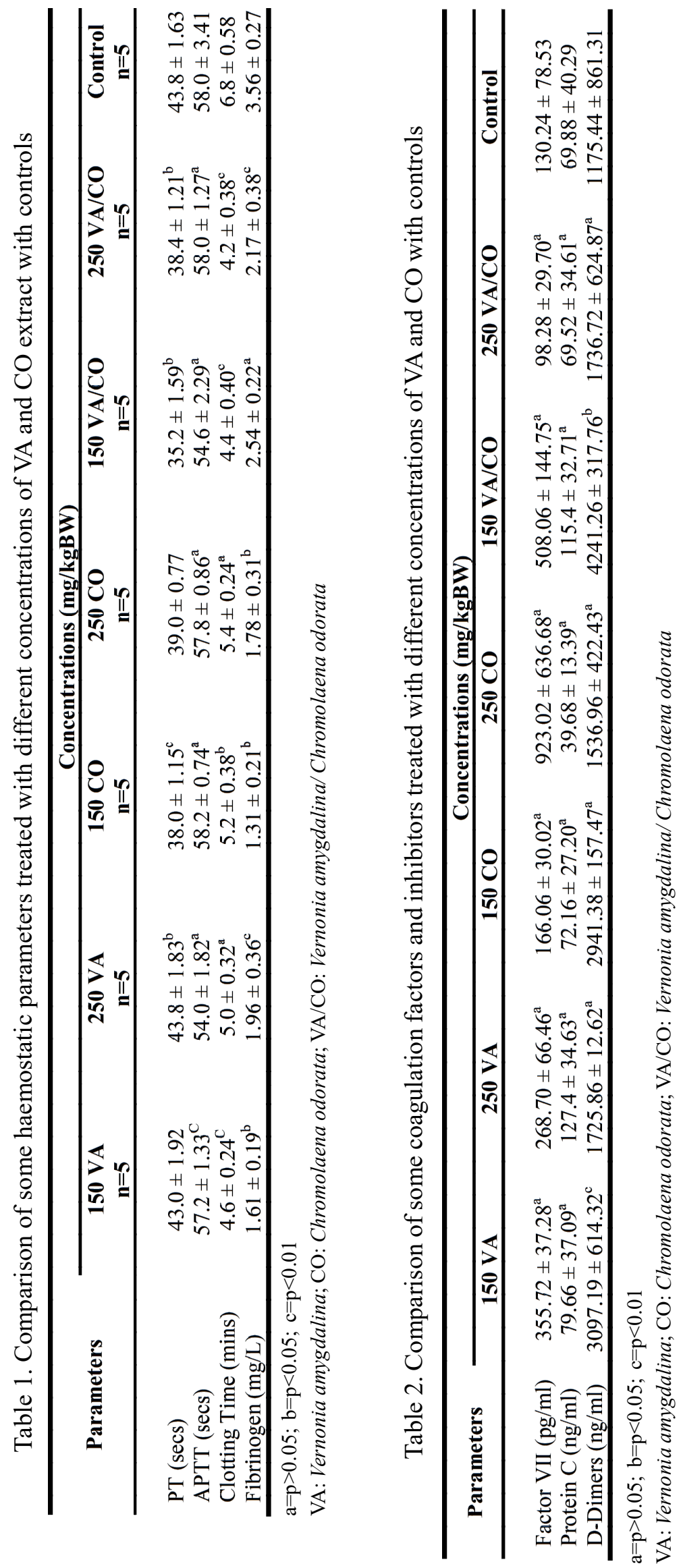


\section{DISCUSSION}

In this study, the haemostatic activities of VA and CO leaf extract was evaluated. There was a significant reduction in the $\mathrm{PT}$ and $\mathrm{CT}$ at $150 \mathrm{mg} / \mathrm{kgBW}$ and $240 \mathrm{mg} / \mathrm{kgBW}$ of both extracts. This may be attributed to the high levels of calcium, vitamin $\mathrm{C}$, proteins and saponins present in the leaves. Although calcium is the principal active ingredient present in plasma and bones, it is the free calcium ions that are physiologically active in the coagulation mechanism. This agrees with another research finding, ${ }^{(9)}$ which demonstrated that the leaves of VA would stop bleeding if squeezed and placed on cuts and wounds of injured vessels. Calcium is essential in the conversion of prothrombin to thrombin. Vernonia amygdalina and $\mathrm{CO}$ leave extracts have been reported to be rich in antioxidant and flavonoids. ${ }^{(17,18)}$ The high antioxidant levels present in the extracts may act in synergy with other phytochemicals which activate endothelial cells to synthesize tissue factors thus promoting haemostasis. Plant extracts are administered to humans in uncontrolled doses by the ethnomedical practitioners. These activities of leaf extracts on blood parameters provides some physiological information on the blood assessment in the body. ${ }^{(18)}$

There was significant reduction in fibrinogen levels with the extract concentrations at $150 \mathrm{mg} /$ $\mathrm{kgBW}$ of VA and CO and at $250 \mathrm{mg} / \mathrm{kgBW}$ of combined extracts when compared with the controls. Fibrinogen is an acute phase protein and its concentration rises in a variety of non-specific conditions such as inflammation, trauma and myocardial infarction. The reduction of fibrinogen in this study indicates that VA and $\mathrm{CO}$ administration reduces and prevents inflammation which may be largely attributed to the presence of flavonoids as contained in the phytochemical constituents of the leaf extracts. High levels of fibrinogen are associated with thrombotic complications. It has been observed that individuals with a fibrinogen level greater than
$4 \mathrm{~g} / \mathrm{L}$ have a two-fold increased risk of venous thrombosis. ${ }^{(24)}$ Methanolic extracts of VA of $100 \mathrm{mg} / \mathrm{kgBW}$ and $200 \mathrm{mg} / \mathrm{kgBW}$ could reduce $40 \%$ and $50 \%$ inhibition against thrombosis in mice. ${ }^{(20,21)}$

Administration of the extracts did not significantly alter the concentrations of factor VII and protein $\mathrm{C}$ when compared with the controls. This may indicate that the leaf extract in enhancing blood clotting does not directly lead to increased production of these clotting factors. DDimers are present in the blood of most healthy individuals in only negligible amounts. Elevated blood levels of D-dimers is evidenced by increase fibrinolysis and thrombotic episodes. ${ }^{(22)}$

In this study, administration of $250 \mathrm{mg} / \mathrm{kg}$ BW of VA and $150 \mathrm{mg} / \mathrm{kgBW}$ of combined VA/ $\mathrm{CO}$ showed a significant increase in D-dimer levels when compared with the controls. This suggests that the extract enhances fibrinolysis thereby facilitating the healing of an injured vessel. Extracts of VA have been shown to have antimicrobial and antiseptic properties. ${ }^{(23)}$ This may also act as a protective mechanism enhancing the complete healing of injured vessels with the administration of these extracts.

The combined effect of VA and CO to injuries especially superficial wounds would reduce hemorrhage. This also has revealed a channel to pharmaceutical companies to incorporate these extracts in drugs used in preventing haemorrhage. Although the present findings suggest the presence of hemostatic compounds in leaf extract of VA and $\mathrm{CO}$, the precise mechanism of its hemostatic action is still speculative and requires further studies for appropriation elucidation.

\section{CONCLUSION}

The leave extracts of VA and $\mathrm{CO}$ shorten the protrombin time, clotting time and decrease fibrinogen levels while D-dimer levels are increased. This implies that the administration of these leave extracts goes a long way in the stoppage of bleeding and aids fibrinolysis. 


\section{CONFLICT OF INTERESTS}

We declare that there is no conflict of interest

\section{ACKNOWLEDGEMENT}

We acknowledge the non-accademic staff of the Department of Anatomy for helping to take care of the animals during the research duration.

\section{AUTHORS CONTRIBUTION}

MOL conceived the study and was responsible for the experimental design and practical implementation. OEO contributed to the experimental design and did the manuscript writeup. All authors have read and approved the final manuscript.

\section{REFERENCES}

1. Schiller AM, Howard JT, Convertion VA. The physiology of blood loss and shock: new insights from a human laboratory model of hemorrhage. Exp Biol Med 2017;242:874-83. doi: 10.1177/ 1535370217694099.

2. Aleman MM, Walton BC, Byrnes JR, et al. Fibrinogen and red blood cells in venous thrombosis. Thromb Res 2014;133:538-40. doi: 10.1016/j.thromres.2014.03.017.

3. Yun S, Sim E, Goh R, et al. Platelet activation: the mechanisms and potential biomarkers. Biomed Res Int 2016;2016:9060143. doi: 10.1155/2016/ 9060143.

4. Kadiri O, Olawoye B. Vernonia amygdalina: an underutilized vegetable with nutraceutical potentials - a review. Turk J Agric Food Sci Technol 2016;4:763-8.

5. Audu SA, Taiwo AE, Ojuolape AR, et al. A study review of documented phytochemistry of Vernonia amygdalina (Family Asteraceae) as the basis for pharmacologic activity of plant extract. J Natural Sci Res 2012;2:1-8.

6. Shokunbi OS, Anionwu OA, Sonuga OS, et al. Effect of post-harvest processing on the nutrient and anti-nutrient compositions of Vernonia amygdalina leaf. Afr J Biotechnol 2011;10: 1098085. doi: 10.5897/AJB11.1532.

7. Krausi I, Tobin G. Discovery, development of natural products in using old solutions to new problems. In: Kulka M,editor.Natural drug discovery in the 21 century. $2^{\text {nd }} \mathrm{ed}$. London, UK: Intech Open; 2013.p.3-36.

8. Lobo VC, Phatak N, Chandra N. Acute toxicity studies of some Indian medicinal plants. PHCOG J 2010;2:207-10.

9. Pandith H, Zhang X, Liggett J, et al. Hemostatic and wound healing properties of Chromolaena odorata leaf extract. ISRN Dermatology 2013; Article ID 168269, 8 pages. DOI: http://dx.doi.org/ 10.1155/2013/168269.

10. Abay M, Lucantoni L, Dahiya N, et al. Plasmodium transmission blocking activities of Vernonia amygdalina extracts and isolated compounds. Malar J2015;14:288. doi: 10.1186/s12936-015-08122.

11. Chinedu E, Arome D, Ameh FS. Anew method for determining acute toxicity in animal models. Toxicol Int 2013;20: 224-6. doi: 10.4103/09716580.121674 .

12. Oguwike FN, Offor CC, Onubeze DPM, et al. Evaluation of activities of Bitterleaf (Vernonia Amygdalina) extract on haemostatic and biochemical profile of induced male diabetic albino rats. IOSR J Dent Med Sci 2013;11:60-4.

13. Sofowora A, Ogunbodede E, Onayade A. The role and place of medicinal plants in the strategies for disease prevention. Afr J Tradit Complement Altern Med 2013;10:210-29. DOI: http://dx.doi.org/ 10.4314/ajtcam.v10i5.2.

14. Olorunfemi EA, Arnold IC, Igbo C, et al. Effects of the leaf extract of Vernonia amygdalina on the pharmacokinetics of dihydroartemisinin in rat. Pharmacologia 2012;3:713-8. doi: $10.5567 /$ pharmacologia.2012.713.718

15. Charan J, Kantharia ND. How to calculate sample size in animal studies? J Pharmacol Pharmacother 2013;4:303-6. doi: 10.4103/0976-500X.119726.

16. Bain BJ, Bates I, Laffan M. Dacie and Lewis practical haematology. $12^{\text {th }}$ ed. Elsevier Ltd.;2016.

17. Alaraa OR, Abdurahman NH, Mudalip SKA, et al. Phytochemical and pharmacological properties of Vernonia amygdalina: a review. J Chem Eng Ind Biotechnol 2017;2:80-96. DOI: https://doi.org/ 10.15282/JCEIB-V2-07.29/9/2017/2.2.

18. Sirinthipaporn A, Jiraungkoorskul W. Wound healing property: review of siam weed, Chromolaena odorata. Pharmacogn Rev 2017;11:35-8. doi: 10.4103/phrev.phrev_53_16.

19. Yeap S, Ho W, Beh BK, et al. Vernonia amygdalina, an enthnoveterinary and ethnomedical used green vegetable with multiple bioactivites. J Med Plants Res 2010;4:2787-812.

20. Asomugha RN, Okafor PN, Ijeh II, et al. Hepatic effects of aqueous extract of Chromolaena 
odorata in male Wistar albino rats. Pharmacol OL 2014;1:127-36.

21. Owolabi MS, Ogundajo A, Yusuf KO, et al. Chemical composition and bioactivity of the essential oil of Chromolaena odorata from Nigeria. Rec Nat Prod 2010;4:72-8.

22. Lippi G, Bonfanti L, Saccenti C, et al. Causes of elevated D-dimer in patients admitted to a large urban emergency department. Eur J Intern Med 2014;25:45-8. doi: 10.1016/j.ejim.2013.07.012.
23. Lyumugabe $\mathrm{F}$, Uyisenga JP, Bayingana $\mathrm{C}$, et al Antimicrobial activity and phytochemicals analysis of Vernonia aemulans, Vernonia amygdalina, Lantana camara and Markhamia lutea leaves as natural beer preservatives. Am J Food Technol 2017;12:35-42. doi: 10.3923/ajft.2017. 35.42 . 